\section{A fatal case of immune hyperhemolysis with bone marrow necrosis in a patient with sickle cell disease}

\author{
Matthew S. Karafin, ${ }^{1,2}$ Arun Singavi, ${ }^{2}$ \\ Susan T. Johnson, ${ }^{1}$ Joshua J. Field ${ }^{1,2}$ \\ ${ }^{1}$ Medical Sciences Institute, Blood \\ Center of Wisconsin, Milwaukee, WI; \\ ${ }^{2}$ Medical College of Wisconsin, \\ Milwaukee, WI, USA
}

\begin{abstract}
In patients with sickle cell disease, hyperhemolysis is a rare but life-threatening complication of transfusion. In this case report, we describe a 61 year-old woman with hemoglobin sickle cell (SC) disease and history of alloimmunization who developed hyperhemolysis associated with a transfusion. She was found to have a warm and a clinically-significant cold autoantibody. Severe anemia ( $\mathrm{Hb} 2.7 \mathrm{~g} / \mathrm{dL}$ ) with reticulocytopenia and thrombocytopenia prompted a bone marrow biopsy, which demonstrated extensive bone marrow necrosis. Despite treatment, the bone marrow failure did not improve and the patient died on hospital day 38. This case illustrates the potential risks of transfusion in a patient with sickle cell disease, especially one with previous hemolytic reactions. While uncommon, hyperhemolysis can cause death, in this case by extensive bone marrow necrosis. In patients with sickle cell disease, judicious use of red cell transfusions with phenotypically-matched units can diminish, but never completely abrogate, the risks associated with transfusion.
\end{abstract}

\section{Introduction}

Sickle cell disease (SCD) is characterized by chronic hemolysis and microvascular occlusion. ${ }^{1}$ Red cell transfusions are frequently used to treat severe anemia and to reduce the effects of sickle cells. ${ }^{2}$ Unlike many patient populations, patients with SCD have a much higher risk of adverse events from transfusion therapy, due in part to known antigen incompatibility between blood donors, who are mostly of European descent, and the blood recipients, who are of African descent. ${ }^{3-5}$ Alloantibody formation in this population can be life-threatening, because delayed hemolytic transfusion reactions (DHTR) may sometimes initiate a hyperhemolytic process whereby there is not only hemolysis of transfused allogeneic cells but also the patient's own autologous cells. ${ }^{3-}$ 5 There are also descriptions of hyperhemolysis associated with autoantibodies, as well as cases with no antibodies. Regardless of whether an antibody is present or not, the end result of these hyperhemolytic events is a profoundly low hemoglobin, even lower than pre-transfusion levels. ${ }^{6}$ Despite profoundly low hemoglobin values, further transfusions can exacerbate the process and worsen the anemia. ${ }^{6}$ In addition to avoidance of transfusions, therapies are often directed at suppressing the immune system (i.e. corticosteroids and IVIg). ${ }^{6-8}$ We report a case of hyperhemolysis in an older patient hemoglobin SC disease. We identified an associated autoantibody that caused robust hemolysis and severe anemia, which was temporally associated with end-organ dysfunction and death. What makes this case unique is that the predominant organ affected was not the brain or the lung, but the bone marrow. The patient in this case developed severe bone marrow necrosis that significantly impaired hematopoiesis. Bone marrow ischemia, the cause of vaso-occlusive pain, is common in $\mathrm{SCD}$; however, extensive bone marrow necrosis is rare. This case underscores the risks associated with transfusion in SCD, especially in a heavily alloimmunized patient.

\section{Case Report}

A 61 year-old female with hemoglobin SC disease on hydroxurea, a history of multiple red cell alloantibodies (anti-E, - $\mathrm{Jk}^{\mathrm{b}}$, $\mathrm{K},-\mathrm{N},-\mathrm{S},-\mathrm{Cw}$, and $-\mathrm{JS}^{\mathrm{a}}$ ) and previous delayed hemolytic transfusion reactions (last recorded red cell transfusion was 3 years before the current admission), a chronic pain syndrome, and G6PD deficiency, presented to the hospital due to a vasoocclusive pain crisis. On admission, her pain was reported to be located in her chest and back, which was similar to her previously reported chronic pain crises. She reported an ongoing viral upper respiratory infection. An admission physical exam demonstrated normal vital signs, respiratory, and cardiac exam. Her presenting laboratory tests were notable for a hemoglobin of $5.3 \mathrm{~g} / \mathrm{dL}$ (baseline of 8-9 g/dL), a platelet count of 120,000 cells/uL (baseline of 140,000 cells/uL), and normal renal function (baseline: $0.8 \mathrm{mg} / \mathrm{dL}$ ). Her urine was free of blood or hemoglobin. The blood bank work-up, however, was significant for a newly positive direct antiglobulin test (DAT) (polyspecific: 1+, anti-IgG: weak,
Correspondence: Matthew S. Karafin, Medical Sciences Institute, BloodCenter of Wisconsin and Medical College of Wisconsin, 8733 Watertown Plank Road Milwaukee, WI 53226, USA.

Tel.: +1.414.937.6809 - Fax: +1.414.937.6803

E-mail: matthew.karafin@bcw.edu

Key words: Bone marrow necrosis, Sickle cell disease, Hyperhemolysis syndrome

Contributions: MK prepared the manuscript including all tables and figures, AS gathered the case data, STJ reviewed the immunohematology data for accuracy and correctness, and JJF provided senior oversight and mentorship on this project and helped prapare the manuscript. All authors reviewed the final manuscript and provided detailed feedback before submission.

Conflict of interest: JJF is a consultant for NKT Therapeutics and receives research funding from NKT Therapeutics and Astellas. No other authors declare a conflict of interest for this manuscript

Conference presentation: a version of this case report was presented at the American College of Physicians: Wisconsin Chapter Annual Meeting (2013).

Received for publication: 13 October 2016. Revision received: 19 November 2016.

Accepted for publication: 21 November 2016.

This work is licensed under a Creative Commons Attribution-NonCommercial 4.0 International License (CC BY-NC 4.0).

(C) Copyright M.S. Karafin et al., 2017

Licensee PAGEPress, Italy

Hematology Reports 2017; 9:6934

doi:10.4081/hr.2017.6934

anti-C3: negative, eluate: negative), and a new anti-McCa, which was considered not clinically significant and has not been reported to cause hemolysis (Table 1 ). ${ }^{9}$ She was started on a hydromorphone patientcontrolled analgesia pump for pain management, and she was transfused two units of least incompatible (incompatibility was from the new anti-McC ${ }^{a}$ ), ABO compatible (patient: $\mathrm{B}+$ ), leukocyte-reduced, sickle negative, and antigen-matched (E-, $\mathrm{Jk}(\mathrm{b}-)$, $\mathrm{K}-$, S,- by serology, and $\mathrm{C}^{\mathrm{w}}$ - and $\mathrm{Js}(\mathrm{a}-)$ by genotype) red blood cells (RBC), with no complications and an appropriate increase in hemoglobin to $7.4 \mathrm{~g} / \mathrm{dL}$. On her second day of admission (HD 2), her platelet count unexpectedly decreased to 61,000 cells/uL, and her count continued to decline through her hospitalization. As her reticulocyte count was also inappropriately low at the 
time $(0.012 \mathrm{e} 6 / \mu \mathrm{L})$, her worsening thrombocytopenia was felt most likely to be due to myelosuppression from hydroxyurea. Consequently, in addition to halting the hydroxyurea, she also received epoetin alfa (40,000 units SQ) for marrow stimulation. Despite holding hydroxyurea and the dose of epoetin, she required an additional 4 units of phenotype-matched RBCs (1 unit HD 5, 1 unit - HD 8, 2 units - HD 12) during the hospitalization to maintain her hemoglobin level. Although immune hemolysis was suspected at the time, no additional antibodies were identified (Table 1). The only detectable antibody was the anti-McCa . After her pain improved, she was discharged on hospital day 12 with a hemoglobin of $9.1 \mathrm{~g} / \mathrm{dL}$ and a platelet count of 20,000 cells/uL (a discharge lactate dehydrogenase $(\mathrm{LDH})$ and total bilirubin were not performed).

At her first outpatient follow-up, 6 days after discharge (about 7 days from her last red cell transfusion), she reported new symptoms of fatigue, shortness of breath, and worsening pain. Her hemoglobin at this visit was $2.7 \mathrm{~g} / \mathrm{dL}$, and platelet count was 20,000 cells/uL. Of note, her reticulocyte percent was below the level of detection $(<0.4 \%)$ despite an erythropoietin level that was elevated at $132 \mathrm{mIU} / \mathrm{mL}$ (reference: 3.7-31.5 mIU/mL). Her laboratory results were consistent with intravascular red cell hemolysis: LDH was $>2500$ U/L (ref: 100$190 \mathrm{U} / \mathrm{L}$, her baseline was $342 \mathrm{U} / \mathrm{L}$ ), haptoglobin was $18 \mathrm{mg} / \mathrm{dL}$ (ref: $30-200 \mathrm{mg} / \mathrm{dL}$ ), and her total bilirubin was $5.0 \mathrm{mg} / \mathrm{dl}$ (ref: $0.2-1.0 \mathrm{mg} / \mathrm{dL}$ ) with hemoglobinuria detected on urine screen. There was no evidence of disseminated intravascular coagulation, and no schistocytes were observed on her peripheral smear. Parvovirus testing was also negative. Her DAT was now strongly positive, with $3+$ polyspecific $\mathrm{AHG}, 1+$ $\mathrm{IgG}, 2+\mathrm{C} 3$ reactivity, and an eluate that was positive with all cells. Of interest, the patient also had a new cold autoantibody with broad specificity and shown to react at body temperature (30 and $37 \mathrm{C}$ ) as defined by thermal amplitude studies, suggesting a clinically-significant mixed (IgG/IgM) autoantibody. No new alloantibodies were detected at this time. All of her red cell units were antigen-matched as before. She was hospitalized again, and was given 2 units of compatible RBCs (with an appropriate immediate post-transfusion response, posttransfusion hemoglobin $5.2 \mathrm{~g} / \mathrm{dl}$ ), epoetin alpha (40,000 units SQ), and prednisone (1 $\mathrm{mg} / \mathrm{kg}$ daily) for a presumed mixed-type (IgG/IgM) hyperhemolysis syndrome (Figure 1). Unfortunately, her pancytopenia worsened despite treatment. On HD 3 of readmission, she was started on intravenous immunoglobulin (IVIg) at $500 \mathrm{mg} / \mathrm{kg}$, received another dose of epoetin alpha (40,000 units), and 2 units of RBCs. She further developed evidence of marrow failure (white count, 2,200 cells/uL) on HD 4 prompting a bone marrow biopsy, which revealed diffuse and widespread bone marrow necrosis (Figure 2). Due to worsening

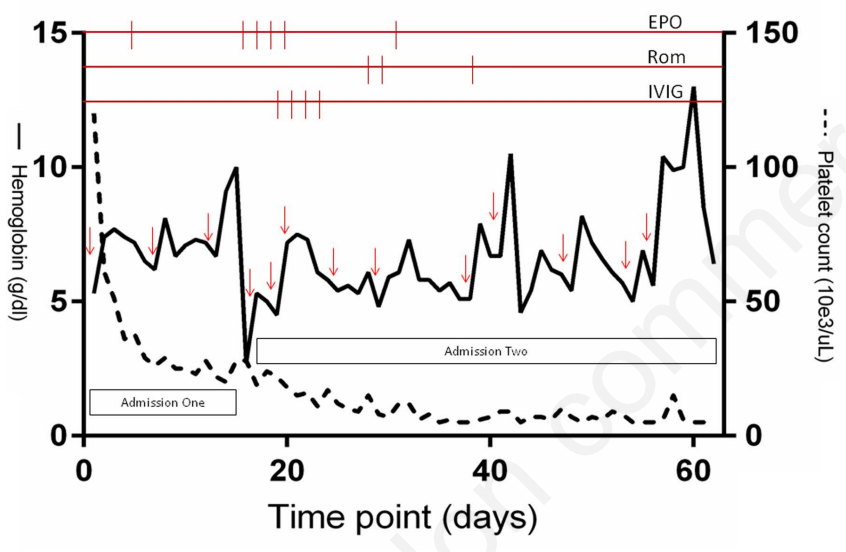

Figure 1. Changes in hemoglobin and platelet count over the patient's two hospitalizations. Each red arrow represents a red cell transfusion event, and each red dash represents a dose of epoetin alpha (EPO), romiplostim (Rom), and intravenous immunoglobulin (IVIG).
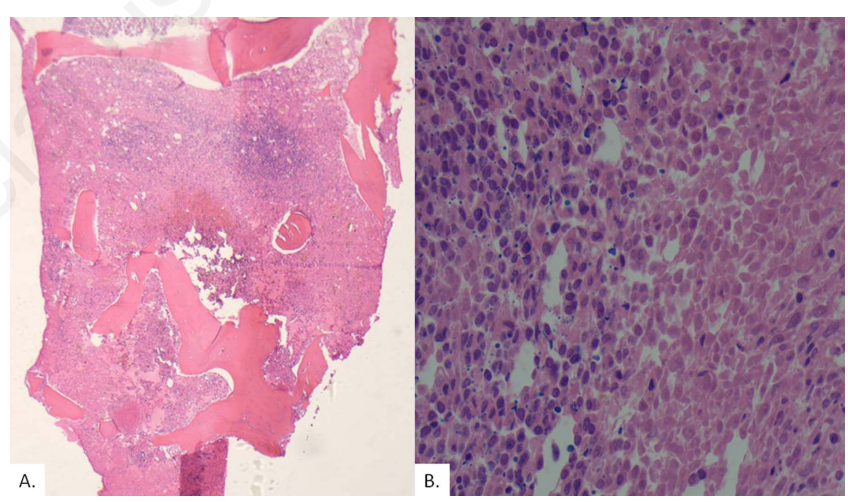

Figure 2. Bone marrow biopsy demonstrating severe bone marrow necrosis. Diffuse bone marrow necrosis is necrosis of myeloid tissue and medullary stroma in large areas of the hematopoetic space on a biopsy, and is characterized by disruption of the normal bone marrow architecture with considerable loss of fat spaces (image A), but normal cortical bone. Notice in image $B$ that all cell lines (including red cell and platelet precursors) have been disrupted.

Table 1. Immuno-hematologic test results during the two hospitalizations.

\begin{tabular}{|c|c|c|c|c|c|c|c|c|c|c|c|}
\hline & $\begin{array}{c}\text { Day } 1 \\
\text { (hosp 1) }\end{array}$ & $\begin{array}{c}\text { Day } 4 \\
\text { (hosp 1) }\end{array}$ & $\begin{array}{c}\text { Day } 11 \\
\text { (hosp 2) }\end{array}$ & $\begin{array}{c}\text { Day } 14 \\
\text { (hosp 2) }\end{array}$ & $\begin{array}{c}\text { Day } 17 \\
\text { (hosp 2) }\end{array}$ & $\begin{array}{c}\text { Day } 21 \\
\text { (hosp 2) }\end{array}$ & $\begin{array}{c}\text { Day } 26 \\
\text { (hosp 2) }\end{array}$ & $\begin{array}{l}\text { Day } 29 \\
\text { (hosp 2) }\end{array}$ & $\begin{array}{l}\text { Day } 34 \\
\text { (hosp 2) }\end{array}$ & $\begin{array}{c}\text { Day } 41 \\
\text { (hosp 2) }\end{array}$ & $\begin{array}{c}\text { Day } 44 \\
\text { (hosp 2) }\end{array}$ \\
\hline Poly IgG & $1+$ & $2+$ & $3+$ & $3+$ & $3+$ & $3+$ & $3+$ & $2+$ & $2+$ & $2+$ & Weak+ \\
\hline Anti-IgG & Weak+ & $1+$ & $1+$ & $1+$ & $2+$ & $2+$ & $2+$ & $1+$ & $1+$ & $1+$ & Weak+ \\
\hline Anti-C3 & 0 & $1+$ & $2+$ & $3+$ & $3+$ & $2+$ & $3+$ & $2+$ & $1+$ & $1+$ & Weak+ \\
\hline Anti-C3d & 0 & Weak+ & $1+$ & Weak+ & Weak+ & $2+$ & $2+$ & $2+$ & $1+$ & $\mathrm{Na}$ & $\mathrm{Na}$ \\
\hline Control & 0 & 0 & 0 & 0 & 0 & 0 & 0 & 0 & 0 & 0 & 0 \\
\hline Eluate & $\begin{array}{l}\text { Neg with all } \\
\text { cells }\end{array}$ & $\mathrm{Na}$ & $\begin{array}{l}\text { Pos with } \\
\text { all cells }\end{array}$ & $\mathrm{Na}$ & $\mathrm{Na}$ & $\mathrm{Na}$ & $\mathrm{Na}$ & $\mathrm{Na}$ & $\mathrm{Na}$ & $\begin{array}{l}\text { Random cells } \\
\text { pos }\end{array}$ & $\begin{array}{l}\text { Neg with } \\
\text { all cells }\end{array}$ \\
\hline Serum & Anti-McCa & $\begin{array}{c}\text { Nothing } \\
\text { new }\end{array}$ & Cold ab & $\begin{array}{c}\text { Nothing } \\
\text { new }\end{array}$ & $\begin{array}{l}\text { Nothing } \\
\text { new }\end{array}$ & $\begin{array}{c}\text { Nothing } \\
\text { new }\end{array}$ & $\begin{array}{c}\text { Nothing } \\
\text { new }\end{array}$ & $\begin{array}{c}\text { Nothing } \\
\text { new }\end{array}$ & $\begin{array}{c}\text { Nothing } \\
\text { new }\end{array}$ & $\begin{array}{c}\text { Nothing } \\
\text { new }\end{array}$ & $\begin{array}{c}\text { Nothing } \\
\text { new }\end{array}$ \\
\hline
\end{tabular}


of her thrombocytopenia, romiplostim (2 $\mathrm{mcg} / \mathrm{kg}$ ) and 2 platelet transfusions were attempted without any meaningful effect on HD 10 (Figure 1). She developed multisystem organ failure and continued to decline cognitively during the hospitalization, and was transitioned to comfort care. She died on HD 38.

\section{Discussion and Conclusions}

We present a unique case of transfusioninduced hyperhemolysis in an adult with SCD. In this heavily alloimmunized, recently-transfused patient, an autoantibody that triggered hyperhemolysis was likely the key insult that ultimately led to her death. Upon presentation with vaso-occlusive pain, the DAT was only weakly positive, but after the patient received red cell transfusions, there was evidence that the autoantibody strengthened. Later in the clinical course, laboratory testing clearly demonstrated complement-coated red cells, as well as a new clinically-significant mixed warm and cold autoantibody. The strengthening of the autoantibody was associated with worsening hemolysis and a clinical picture consistent with acute hyperhemolysis: a recent transfusion (about 7 days before the hemoglobin nadir), a new red cell antibody, reticulocytopenia, and a severe anemia (well below pre-transfusion levels).

Unfortunately, in this case, the severe anemia and resultant ischemia from red cell hemolysis likely fatally exacerbated extensive, clinically-significant bone marrow necrosis; a process that likely began during her first hospitalization as reflected by her progressively strengthening DAT and worsening thrombocytopenia during that time period.

Hyperhemolysis syndrome is a wellreported and life-threatening complication of red cell transfusions for patients with SCD. Recent studies estimate its incidence to be $1-19 \% .^{4,10}$ Clinically, the typical presentation of acute hyperhemolysis is severe anemia, developing about 7 days after a previous transfusion, with a hemoglobin that is lower than pre-transfusional levels. ${ }^{6}$ Other common findings include reticulocytopenia, pain, fever, and signs of hemolysis, including jaundice, increased LDH, hyperbilirubinemia, and hemoglobinuria., 4 While hyperhemolysis has no definitive diagnostic test, there is sometimes evidence of a new allo- or autoantibody. ${ }^{6,10}$

The pathophysiology of red cell hyperhemolysis is poorly understood. What is known is that both donor and recipient red cells are hemolyzed. ${ }^{4,6}$ One potential reason for the autologous RBC destruction in these patients is the formation of a nonspecific antibody that binds complement and destroys both donor and recipient red cells, known as bystander hemolysis. 6,11 As in our patient, previous studies have shown a strong association between the formation of nonspecific autoantibodies and the history of previous transfusions. ${ }^{12}$ Another explanation for excess patient RBC destruction is the hyperactive phagocytic activity of macrophages. ${ }^{13}$ Of note, sickled RBCs expose some antigens (e.g. phosphatidylserine) on their outer surface, which some theorize can allow recognition by activated macrophages without antibody interactions. ${ }^{14}$ Others consider the interaction between VCAM- 1 and $\alpha 4 \beta 1$ on sickled red cells, and CD11c and ICAM-4 on transfused donor red cells, to be critical for antibody-independent phagocytosis by activated macrophages in patients with SCD. ${ }^{6}$ Lastly, suppression of erythropoiesis has also been proposed as a cause or modulator of the disease. ${ }^{6}$ A low reticulocyte count certainly contributed to our patient's anemia. The severity of this patient's anemia (hemoglobin of $2.7 \mathrm{~g} / \mathrm{dL}$ ), was notable. The reason for the severity was likely two-fold. First, as mentioned above, this patient had an ongoing reticulocytopenia that prevented an appropriate response in the face of hemolysis. The reticulocytopenia may have developed from bone marrow necrosis and, potentially, the immune-mediated hemolysis of red cell precursors as well. Second, the cold autoantibody active at $\geq 30^{\circ} \mathrm{C}$ likely contributed to a more severe hemolysis. A recent study suggests that mixed-type immune hemolytic anemias may be more severe than other forms of immune hemolysis, with $63 \%$ of mixed hemolysis patients presenting with a hemoglobin $<6 \mathrm{~g} / \mathrm{dL}$ in comparison to $29 \%$ of patients with typical warm autoimmune hemolytic anemia, and $9 \%$ of patients with cold agglutinin disease, respectively. ${ }^{15}$ Moreover, hyperhemolysis in a patient with SCD and a clinically significant cold autoantibody, anti-IH, has contributed in at least one reported fatal outcome from hyperhemolysis. ${ }^{16}$ Our case, however, is the first where the hemolysis from a mixed-type auto agglutinin led to profound bone marrow failure.

Extensive bone marrow necrosis that affects hematopoiesis is a rare, but established, complication in patients with SCD. ${ }^{17}$ Greater than $90 \%$ of cases of bone marrow necrosis occur in the context of other diseases such as cancer, most often hematological malignancy, infection or autoimmune conditions. ${ }^{17}$ Bone marrow necrosis in SCD encompasses a broad spectrum of severity, from a localized process to one that is wide- spread. ${ }^{18}$ Given that one of the most common sites for vaso-occlusion is in the bone marrow, aspirates often reveal patches of necrotic marrow, although rarely extensive enough to impact hematopoiesis, as was seen in our case. ${ }^{18,19}$ Common symptoms of bone marrow necrosis include back pain, fever, cytopenias and a leukoerythroblastic picture (immature white blood cells and nucleated red cells in peripheral blood). ${ }^{18}$ Large autopsy studies suggest that the prevalence of diffuse bone marrow necrosis can range from $0.2-15$ percent of susceptible patients. ${ }^{18}$ As of 2016 , about 60 cases of severe bone marrow necrosis in patients with SCD has been reported in the literature. $^{20}$ To our knowledge, none of these were reported to be precipitated by a previous red cell transfusion. Of those reported cases, $64 \%$ had a fatal outcome and only 12 patients $(21 \%)$ documented complete recovery, all after receiving red blood cell exchanges. ${ }^{20}$ Death from extensive marrow necrosis is secondary to the dissemination of fat emboli, acute multi-organ system failure, and acute chest syndrome episodes. ${ }^{18-20}$

There is no standard approach to the treatment of hyperhemolysis or extensive bone marrow necrosis. In the case of hyperhemolysis, transfusion of red cells is usually avoided, because it may precipitate increased bystander hemolysis and macrophage activation. ${ }^{6}$ Our patient did receive red cell transfusions, especially when the clinical picture was unclear during her first admission. These transfusions may have exacerbated her condition. Otherwise, our patient was treated with steroids and IVIg to decrease antibody production and reduce the clearance of antibody-laden red cells, as has been reported to be beneficial in the literature. ${ }^{6-8}$ Growth factors are also a mainstay, especially epoetin alpha, since reticulocytopenia is often a presenting feature. Erythropoietin can correct anemia by stimulating red cell precursors and also mitigate the destruction of young red cells. ${ }^{6}$ Additionally, rituximab (anti-CD20) has been used in some cases with success. ${ }^{21}$ While we had some evidence that the patient's immune hemolysis was improving (her direct antiglobulin test was showing weakening of her IgG and C3 values during her second hospitalization), these therapies likely had no impact on her final outcome as none of these therapies will aid in bone marrow recovery. Simple or exchange red cell transfusions may be beneficial for bone marrow necrosis to improve oxygenation and blood flow to the ischemic marrow; ${ }^{18-20}$ unfortunately, aggressive transfusion therapy was not an option for our patient.

This case demonstrates the unique risks of red cell transfusions in a patient with 
SCD. Severe anemia associated with hyperhemolysis was likely what caused the bone marrow necrosis that ultimately led to this patient's death. The bone marrow biopsy, which ultimately clarified her pancytopenia, should be seriously considered in patients with SCD when severe anemia, reticulocytopenia, and thrombocytopenia are observed together. In conclusion, an awareness of the potential for serious complications, such as hyperhemolysis, is necessary when determining the need for transfusion in a patient with SCD.

\section{References}

1. Rees DC, Williams TN, Gladwin MT. Sickle-cell disease. Lancet 2010;376: 2018-31.

2. Yawn BP, Buchanan GR, Afenyi-Annan AN, et al. Management of sickle cell disease. Summary of the 2014 evidence-based report by expert panel members. JAMA 2014;312:1033-48.

3. Chou ST. Transfusion therapy for sickle cell disease: a balancing act. Hematology Am Soc Hematol Educ Program 2013;2013:439-46.

4. Talano JA, Hillery CA, Gottschall JL, et al. Delayed hemolytic transfusion reaction/ hyperhemolysis syndrome in children with sickle cell disease. Pediatrics 2003;111:e661-5.

5. Aygun B, Padmanabhan S, Paley C, Chandrasekaran V. Clinical significance of RBC alloantibodies and autoantibod- ies in sickle cell patients who received transfusions. Transfusion 2002;42:3743.

6. Win N. Hyperhemolysis syndrome in sickle cell disease. Expert Rev Hematol 2009;2:111-5.

7. de Montalembert M, Dumont MD, Heilbronner C, et al. Delayed hemolytic transfusion reaction in children with sickle cell disease. Haematologica 2011;96:801-7.

8. Scheunemann LP, Ataga KI. Delayed hemolytic transfusion reaction in sickle cell disease. Am J Med Sci 2010;339: 266-9.

9. Reid ME, Lomas-Francis C, Olsson ML. The blood group antigen facts book. 3rd ed. London: Elsevier; 2012.

10. Garratty G. What do we mean by hyperhaemolysis and what is the cause? Transfus Med 2012;22:77-9.

11. King KE, Shirey RS, Lankiewicz MW, et al. Delayed hemolytic transfusion reactions in sickle cell disease: simultaneous destruction of recipients' red cells. Transfusion 1997;37:376-81.

12. Ahrens N, Pruss A, Kähne A, et al. Coexistence of autoantibodies and alloantibodies to red blood cells due to blood transfusion. Transfusion 2007;47: 813-6.

13. Win N, New H, Lee E, de la Fuente J. Hyperhemolysis syndrome in sickle cell disease: case report (recurrent episode) and literature review. Transfusion 2008;48:1231-8.

14. Chadebech P, Habibi A, Nzouakou R, et al. Delayed hemolytic transfusion reac- tion in sickle cell disease patients: evidence of an emerging syndrome with suicidal red blood cell death. Transfusion 2009;49:1785-92.

15. Barcellini W, Fattizzo B, Zaninoni A. Clinical heterogeneity and predictors of outcome in primary autoimmune hemolytic anemia: a GIMEMA study of 308 patients. Blood 2014;124:2930-6.

16. Ibanez C, Habibi A, Mekontso-Dessap $\mathrm{A}$, et al. Anti-HI can cause a severe delayed hemolytic transfusion reaction with hyperhemolysis in sickle cell disease patients. Transfusion 2016;56; 1828-33.

17. Wool GD, Deucher A. Bone marrow necrosis: ten-year retrospective review of bone marrow biopsy specimens. Am J Clin Pathol 2015;143:201-13.

18. Ataga KI, Orringer EP. Bone marrow necrosis in sickle cell disease: a description of three cases and review of the literature. Am J Med Sci 2000;320:342-7.

19. Charache S, Page DL. Infarction of the bone marrow in sickle cell disorders. Ann Intern Med 1967;67:1195-2000.

20. Tsitsikas DA, Gallinella G, Patel S, et al. Bone marrow necrosis and fat embolism syndrome in sickle cell disease: increased susceptibility of patients with non-SS genotypes and a possible association with human parvovirus B19 infection. Blood Rev 2014;28:23-30.

21. Bachmeyer C, Maury J, Parrot A, et al. Rituximab as an effective treatment of hyperhemolysis syndrome in sickle cell anemia. Am J Hematol 2010;85:91-2. 